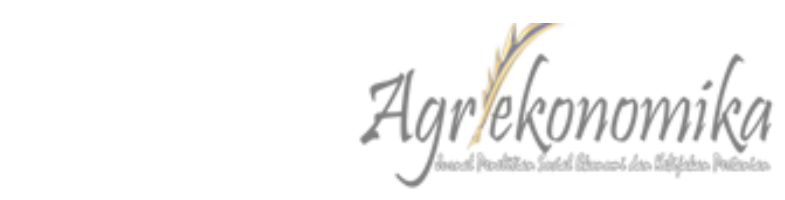

Jurnal Sosial Ekonomi dan Kebijakan Pertanian

http://journal.trunojoyo.ac.id/agriekonomika

Agriekonomika Volume 5, Nomor 2, 2016

\title{
KAPASITAS PENYULUH PERTANIAN DALAM UPAYA MENINGKATKAN PRODUKTIVITAS PERTANIAN DI JAWA TIMUR
}

\author{
Aryo Fajar Sunartomo \\ Program Studi Agribisnis, Fakultas Pertanian, Universitas Jember \\ aryofajar74@yahoo.com
}

Received : 12 April 2016; Accepted: 19 Agustus 2016; Published: 31 Oktober 2016

DOI: http://dx.doi.org/10.21107/agriekonomika.v5i2.1343

\begin{abstract}
ABSTRAK
Propinsi Jawa Timur merupakan salah penyedia produk-produk pertanian. Oleh karena itu penguatan sektor pertanian melalui program peningkatan produktifitas perlu dilakukan dimana salah satunya berhubungan dengan peran penyuluh pertanian. Tujuan dari kegiatan penelitian ini adalah mengukur kinerja penyuluh pertanian dalam rangka meningkatkan produktifitas pertanian di Jawa Timur. Pendekatan penelitian ini menggunakan pendekatan/metode deskriptif, analitik dan korelasional. Daerah penelitian dilaksanakan secara purposive method pada 4 (empat) kabupaten di Jawa Timur, yaitu Jember, Banyuwangi, Nganjuk, dan Kediri. kinerja penyuluh pertanian dalam rangka peningkatan produksi pertanian Di Jawa Timur memiliki kategori sangat baik. Strategi Kebijakan Penyuluhan yang tepat untuk meningkatkan produktivitas pertanian adalah meningkatkan program-program terkait kelembagaan, kuantitas dan kualitas penyuluh serta perbaikan kelembagaan kelompok tani. Tujuan yang harus dicapai adalah peningkatan mutu penyuluhan pertanian, sasaran dari tujuan tersebut adalah peningkatan kualitas dan kuantitas penyuluh melalui pendidikan dan pelatihan, serta pemberdayaan kelompok tani adalah meningkatkan program-program terkait kelembagaan, kuantitas dan kualitas penyuluh serta perbaikan kelembagaan kelompok tani. Tujuan yang harus dicapai adalah peningkatan mutu penyuluhan pertanian, sasaran dari tujuan tersebut adalah peningkatan kualitas dan kuantitas penyuluh melalui pendidikan dan pelatihan, serta pemberdayaan kelompok tani.
\end{abstract}

Kata kunci : Penyuluh Pertanian, Kinerja, Produktifitas Pertanian

AGRICULTURAL EXTENSION CAPACITY IN EFFORTS TO INCREASE AGRICULTURAL PRODUCTIVITY IN EAST JAVA

\begin{abstract}
East Java province is one of provider agricultural products. Therefore, the strengthening of the agricultural sector through productivity improvement programs need to be done, which one the strengthening of the agricultural sector relates to the role of agricultural extension. The purpose of this research activity is to measure the performance of agricultural extension in order to increase agricultural productivity in East Java. This research approach using method descriptive, analytical and correlational. Research area by purposive method in 4 (four) districts in East Java, that is Jember, Banyuwangi, Nganjuk and Kediri. Agricultural Extension Performance in order to increase agricultural production in East Java has a very good category. Right Extension Policy Strategy to improve agricultural productivity is improving programs related to institutional, quantity and quality of the extension and improvement of farmers groups. Goals to be achieved are improving the quality of agricultural extension, the target of these objectives is to increase the quality and quantity of extension through education and training, as well as the empowerment of farmer groups.
\end{abstract}

Keywords : Agricultural Extension, Performance, Productivity Agriculture

Corresponding author:

Address : Perum Taman Kampus C7/16a

Email : aryofajar74@yahoo.com

(C) 2016 Universitas Trunojoyo Madura p-ISSN 2301-9948 | e-ISSN 2407-6260 


\section{PENDAHULUAN}

Provinsi Jawa Timur merupakan salah satu lumbung pangan nasional dan juga sebagai penyedia produk-produk pertanian lainnya seperti hortikultura dan perkebunan. Oleh karena itu maka penguatan sektor pertanian melalui program peningkatan produksi perlu dilakukan secepatnya agar pencapaian swasembada segera dapat diwujudkan. Berkaitan dengan produksi pertanian salah satunya berhubungan dengan peran penyuluhan pertanian. Penyuluhan pertanian adalah pendidikan non formal yang ditujukan kepada para petani dan keluarganya dengan tujuan jangka pendek untuk mengubah perilaku, tindakan, sikap, dan pengetahuan yang lebih baik, serta jangka panjang agar petani dapat hidup sejahtera (Van den Ban dan Hawkins, 1999).

Hubungan antara petani dan penyuluh adalah terkait dalam bagaimana penyuluh dapat merubah tingkat pengetahuan, keterampilan, dan sikap petani dan keluarganya menjadi mandiri. Berkaitan dengan hal tersebut menurut Azhar (2010) bahwa tingkat kepuasan dari petani dan penyuluh terhadap kinerja penyuluh yaitu terdapat hubungan signifikan. Selain itu menurut Muslihat (2015), bahwa semakin tinggi kompetensi maka akan semakin tinggi pula tingkat kompetensinya dalam melaksanakan tugas - tugasnya.

Terkait dengan faktor-faktor internal yang dapat meningkatkan kinerja penyuluh pertanian menurut Bahua (2010), adalah: umur, masa kerja, jumlah petani binaan, kemampuan merencanakan program penyuluhan, kemampuan kepemimpinan penyuluh, pengembangan potensi diri, kebutuhan untuk berafiliasi, kemandirian intelektual dan kemandirian sosial. Selain itu, menurut Kusmiyati (2010), faktor eksternal yang mendukung kinerja penyuluh dalam melaksanakan tupoksi yaitu kebijakan pemerintah (Kelembagaan, dana, sarana), meskipun jumlah tenaga penyuluh belum sesuai dengan kebijakan Deptan.
Pada hubungannya dengan kegiatan penyuluhan pertanian dalam upaya memberdayakan petani, menurut Marliati (2008), tingkat kinerja penyuluh pertanian yang berpengaruh nyata terhadap kinerja penyuluh pertanian yaitu: karakteristik sistem sosial (nilai-nilai sosial budaya, fasilitasi agribisnis oleh lembaga pemerintah dan akses petani terhadap kelembagaan agribisnis) dan kompetensi penyuluh (kompetensi komunikasi, kompetensi penyuluh membelajarkan petani dan kompetensi penyuluh berinteraksi sosial).

Berkenaan dengan upaya menciptakan ketersediaan pangan, maka tujuan dari kegiatan penelitian Kajian Pengembangan Kapasitas Penyuluh Pertanian Dalam Upaya Meningkatkan Produktivitas Pertanian di Jawa Timur ini adalah mengukur kinerja penyuluh pertanian dalam rangka meningkatkan produktifitas pertanian di Jawa Timur dan merumuskan strategi kebijakan penyuluhan yang tepat untuk meningkatkan produktifitas pertanian di Jawa Timur.

\section{METODE PENELITIAN}

Pendekatan penelitian ini menggunakan pendekatan/metode deskriptif, analitik dan korelasional (Nazir, 2005). Untuk pelaksanaan penelitian dilaksanakan secara purposive method pada 4 (empat) kabupaten di Jawa Timur, yaitu Kabupaten Jember, Kabupaten Banyuwangi, Kabupaten Nganjuk, dan Kabupaten Kediri. Teknik pengumpulan data yang digunakan dalam penelitian ini adalah: a. Wawancara, b.Kuesioner, c. Observasi dan d. Studi Pustaka.

\section{HASIL DAN PEMBAHASAN \\ Kinerja Penyuluh Pertanian dalam Rangka Peningkatan Produktifitas Pertanian di Jawa Timur}

Penilaian kinerja penyuluh pertanian berdasarkan pada SK. Menteri Pertanian No. 671 tahun 2006 yang berisi tentang 9 (Sembilan) indikator keberhasilan penyuluh pertanian. Berikut penjelasan dari setiap indikator. 
Tersusunnya Program Penyuluhan Pertanian sesuai dengan Kebutuhan Petani

Hal pertama yang harus dilakukan Penyuluh Pertanian adalah menyusun programprogram yang tentu saja sesuai dengan kebutuhan petani. Ini penting dilakukan agar penyuluhannya tepat sasaran dan dapat diaplikasikan oleh petani. Penilaian responden terhadap indikator Tersusunnya Program Penyuluhan Pertanian sesuai dengan Kebutuhan Petani dapat dilihat pada tabel 1.

Pada Tabel 1, menunjukkan bahwa 40 responden menilai penyusunan program penyuluhan pertanian yang dilakukan oleh penyuluh pertanian di Jawa Timur telah sesuai dengan kebutuhan petani. Dengan demikian sebanyak 40 responden memberi skor 3 sehingga jumlah total skor ialah 120. Hal ini berarti indikator Tersusunnya Program Penyuluhan Pertanian sesuai dengan Kebutuhan Petani berada pada kategori sangat baik. Dengan demikian menunjukkan bahwa kinerja penyuluh dalam penyusunan program penyuluhan sangat baik. Terbukti berdasarkan observasi petani menyatakan merasa puas dengan program-program yang disusun dan dijalankan oleh penyuluh.

\section{Tersusunnya Rencana Kerja Penyuluhan Pertanian di Wilayah Kerja Masing-Masing}

Penyusunan rencana kerja penting sebagai acuan dasar para penyuluh dalam menjalankan tugasnya, agar lebih terarah dan tepat waktu. Berikut adalah hasil penilaian responden terhadap indikator penyusunan rencana kerja yang terangkum pada Tabel 2 .
Dari Tabel 2, memperlihatkan penilaian penyuluh terhadap indikator tersusunnya rencana kerja penyuluhan pertanian mempunyai skor 3 (tiga) karena penyusunan program-program beserta dengan rencana kerja selama periode waktu tertentu dilakukan oleh penyuluh. Perkembangan pelaksanaannya pada saat ini telah dan sedang berlangsung. Sebagian besar petani memberikan nilai skor 3 (tiga) karena dalam penyusunan rencana kerja juga melibatkan petani dan petani merasa puas dengan rencana kerja yang tersusun tersebut. Ada sebagian petani yang memberikan nilai skor 2 (dua), ini disebabkan belum terlaksananya beberapa rencana. Total skor dari keseluruhan responden adalah 117, nilai ini masuk dalam range berkategori sangat baik, berarti kinerja penyuluh dalam penyusunan rencana kerja sangat baik. Hal ini dikarenakan selain dibuat dari awal yang melibatkan atasan dan petani, rencana kerja juga bermanfaat dalam mengidentifikasi masalah - masalah yang dihadapi petani. Upaya yang dilakukan penyuluh untuk mengatasi masalah yang dihadapi para petani selalu dikoordinasikan dengan tokoh masyarakat dan instansi terkait.

Sebagian besar petani menyatakan bahwa tugas penyuluh dalam membuat catatan rencana kerja dan realisasi kegiatan sebagai upaya penyuluh untuk ditindaklanjuti termasuk kategori sanagat baik. Catatan tentang rencana kerja dan realisasi kegiatan sebagai upaya penyuluh untuk memudahkan pelaksanaan kerja dijadikan pedoman untuk mengevaluasi kegiatan yang sudah berjalan maupun setelah selesai melaksanakan kegiatan.

Tabel 1

Hasil Penilaian Responden terhadap Indikator Tersusunnya Program Penyuluhan Pertanian

\begin{tabular}{lccc}
\hline Kategori & Skor & & Persentase (\%) \\
\hline Telah Sesuai & 3 & 40 & 100,00 \\
Kurang Sesuai & 2 & 0 & 0,00 \\
Tidak tersedia & 1 & 0 & 0,00 \\
Total & 120 & 40 & 100,00 \\
\hline
\end{tabular}

Sumber : Data Primer Diolah, 2015 
Tabel 2

Hasil Penilaian Responden terhadap Indikator Tersusunnya Rencana Kerja Penyuluhan Pertanian

\begin{tabular}{lccc}
\hline \multicolumn{1}{c}{ Kategori } & Skor & N & Persentase (\%) \\
Sudah tersusun dan sedang dilaksanakan & 3 & 37 & 92,50 \\
Sudah tersusun dan belum dilaksanakan & 2 & 3 & 7,50 \\
Belum tersusun & 1 & 0 & 0,00 \\
Total & 117 & 40 & 100,00 \\
\hline
\end{tabular}

Sumber : Data Primer Diolah, 2015

Menurut Van de Ban dan Hawkins (1996), penyuluhan merupakan keterlibatan seseorang untuk melakukan komunikasi informasi secara sadar dengan tujuan untuk membantuk sesamanya memberi pendapat sehingga bisa membuat keputusan yang benar. Maka dari itu penyuluh berusaha melibatkan partisipasi petani mengenal daerahnya sendiri, sehingga pada saat musyawarah desa, para perwakilan petani mempunyai kesepakatan untuk mengembangkan daerahnya sendiri. Tabel 3, menunjukkan bahwa sebagian besar responden memberikan nilai skor 3 (tiga), sehingga total skor yang diperoleh adalah 115 (termasuk range kategori sangat baik). Berarti tugas penyuluh pertanian dalam mengidentifikasi potensi wilayah termasuk kategori sangat baik. Hal ini berkaitan dengan upaya penyuluh pertanian untuk membentuk tim tiap kelompok tani yang terlibat dalam menganalisis potensi wilayah desa dan agroekosistem untuk bersama-sama sebagai bahan penyusunan program penyuluhan dan menggali potensi desa untuk mencari peluang pengembangan komoditas.

Terdiseminasinya Informasi Teknologi Pertanian secara Merata dan Sesuai dengan Kebutuhan Petani

Informasi mengenai teknologi pertanian selalu disampaikan setiap adanya forum penyuluhan agar petani lebih mengetahui perkembangan teknologi atau inovasi dalam dunia pertanian. Hal ini dilakukan guna meningkatkan kualitas sumberdaya manusia (petani) terutama dalam hal pengolahan usahatani sampai pada hasil produksi dan pemasaran agar ada nilai tambah dan daya saing produk yang dihasilkan. Berikut hasil penilaian tentang indikator terdiseminasinya informasi teknologi pertanian secara merata dan sesuai dengan kebutuhan petani yang terangkum pada tabel 4 . Pada tabel 4, memperlihatkan ada sebagian petani yang merasa bahwa informasi teknik produksi yang diberikan kurang sesuai dengan kebutuhan petani, hal ini disebabkan petani tidak menguasai atau kurang mengerti informasi yang diberikan oleh penyuluh. Budidaya tanaman dengan cara penggunaan teknologi baru, penggunaan benih unggul dan informasi yang menyangkut perbaikan cara tanam serta penggunaan pupuk/pestisida telah disampaikan penyuluh, namun belum secara keseluruhan para petani mengadopsi.

Meskipun demikian sebagian besar petani responden berpendapat bahwa penyebarluasan informasi baik teknologi usahatani maupun kebijakan yang berasal dari pemerintah termasuk kategori sangat baik. Hal ini terlihat bahwa sebanyak 34 responden memberi nilai skor 3 (tiga) dan 6 (dua) responden memberi nilai skor 2 (dua), sehingga total skor ialah 108 termasuk dalam range kategori sangat baik. Penyuluh telah berusaha untuk memberikan informasi kepada petani sesuai dengan yang diperoleh penyuluh baik tentang teknologi usahatani maupun informasi dari pihak pemerintah. Dukungan brosur/folder dan leaflet sebagian petani menyatakan 
Tabel 3

Hasil Penilaian Responden terhadap Indikator Tersedianya Data Peta Wilayah Untuk Pengembangan Teknologi Spesifik Lokasi

$\begin{array}{lccc}\text { Kategori } & \text { Skor } & \text { N } & \text { Persentase (\%) } \\ \text { Telah Tersedia } & 3 & 35 & 87,50 \\ \text { Telah Tersedia Tetapi Kurang Sesuai } & 2 & 5 & 12,50 \\ \text { Tidak tersedia } & 1 & 0 & 0,00 \\ \text { Total } & 115 & 40 & 100,00\end{array}$

Sumber: Data Primer Diolah, 2015

baik yaitu karena mereka memperoleh informasi tersebut langsung dari penyuluh meskipun belum secara keseluruhan petani memperoleh brosur/folder tersebut.

Tumbuh Kembangnya Keberdayaan dan Kemandirian Petani, Kelompok Tani, Kelompok Usaha/Asosiasi dan Usaha Formal

Keberdayaan dan kemandirian petani merupakan salah satu tujuan dari penyuluhan, namun survey lapangan mendapatkan hasil yang tidak diharapkan. Hasil penilaian indikator keberdayaan dan kemandirian petani yang terangkum pada Tabel 5, menunjukkan 29 responden memberikan nilai 3 (dua), 10 responden menilai 2 (dua) selebihnya menilai 1 (satu) sehingga total skor yang diperoleh ialah 108 yang berarti termasuk dalam kategori baik.

Keadaan ini disebabkan adanya peningkatan jumlah kelompok tani, namun dalam pengembangan swadaya dan swakarsa petani menunjukkan bahwa sebagian besar petani di wilayah ini masih mempunyai sifat ketergantungan terhadap bantuan pihak lain dalam pengembangan usahataninya. Keterbatasan modal adalah salah satu hal yang menyebabkan petani sulit bersaing. Petani lebih bergantung pada para tengkulak untuk memperoleh dana, karena cepat dan lebih mudah. Selain itu, sikap merasa puas atas cara tradisional dalam mengolah usahataninya juga mengakibatkan petani tidak bisa mengembangkan potensi usahataninya.

Upaya terus dilakukan oleh penyuluh pertanian dalam memfasilitasi forum penyuluhan sebagai upaya dalam melaksanakan proses pembelajaran dalam melakukan usahatani berorientasi agribisnis. Penyuluh berusaha menginformasikan teknologi maupun permodalan yang sangat dibutuhkan oleh petani dengan bekerjasama instansi terkait untuk memberikan kemudahan dan persyaratan yang diperlukan.

\section{Terwujudnya Kemitraan Usaha Antara Petani dengan Pengusaha yang Saling Menguntungkan}

Kemitraan usaha antara petani dan pengusaha sangat penting terutama dalam hal pemasaran hasil produksi agar lebih jelas dan terarah. Hubungan

\section{Tabel 4}

Hasil Penilaian Responden terhadap Indikator Terdiseminasinya Informasi

Teknologi Pertanian secara Merata dan sesuai dengan Kebutuhan Petani

\begin{tabular}{lccc} 
Kategori & Skor & $N$ & Persentase (\%) \\
Merata Dan Sesuai Dengan Kebutuhan Petani & 3 & 34 & 85,00 \\
Merata Tdk Sesuai Dengan Kebutuhan Petani & 2 & 6 & 15,00 \\
Tidak T Merata Tdk Sesuai Dengan Kebutuhan Petani & 1 & 0 & 0,00 \\
Total & 114 & 40 & 100,00 \\
\hline
\end{tabular}

Sumber : Data Primer Diolah, 2015 
Tabel 5

Hasil Penilaian Responden terhadap Indikator keberdayaan dan Kemandirian Petani, Kelompok Tani, Kelompok Usaha/Asosiasi dan Usaha Formal

\begin{tabular}{lccc} 
Kategori & Skor & N & Persentase (\%) \\
Telah Mandiri Dan Berdaya Saing Tinggi & 3 & 29 & 72,50 \\
Telah Mandiri Tetapi Tidak Berdaya Saing & 2 & 10 & 25,00 \\
Tidak Mandiri Dan Tidak Berdaya Saing & 1 & 1 & 2,50 \\
Total & 108 & 40 & 100,00 \\
\hline
\end{tabular}

Sumber: Data Primer Diolah, 2015

kemitraan akan berpengaruh pada harga dari hasil produksi usahatani, sehingga mampu meningkatkan kesejahteraan petani. Berikut hasil penilaian terhadap indikator terwujudnya kemitraan usaha antara petani dengan pengusaha,yang terangkum dalam tabel 6. Pada tabel 6 , memperlihatkan penyuluh memberikan nilai skor 3 (tiga), karena berdasarkan wawancara dijelaskan bahwa penyuluh telah memberikan informasi tentang kemitraan dan mengupayakan terjalinnya hubungan antara petani dan mitra usaha, namun belum ada petani yang memiliki mitra pengusaha, hanya 12 (dua belas) petani yang menyatakan belum memiliki mitra usaha dan sisanya 28 petani tidak memiliki mitra pengusaha.

Sebagian besar petani menilai bahwa upaya yang telah dilakukan penyuluh kurang optimal, hal ini terbukti tidak adanya realisasi kerjasama oleh mitra usaha yang dijembatani oleh penyuluh dan hanya sedikit saja petani yang hampir menjalin hubungan kemitraan. Oleh karena itu nilai skor yang diberikan petani pada indikator ini rendah sehingga total nilai skor yang diperoleh ialah 52, termasuk dalam range kategori kurang baik. Hal ini berarti kinerja penyuluh untuk mewujudkan kemitraan usaha antara petani dengan pengusaha masih kurang baik.

Terwujudnya Akses Petani ke Lembaga Keuangan, Informasi Sarana Produksi Pertanian dan Pemasaran

Proses dalam usahatani dari awal sampai pada hasil panen dan pemasaran sangat membutuhkan dana, kecukupan sarana produksi dan adanya mitra usaha pemasaran. Oleh karena itu sangatlah penting bagi petani untuk bisa mendapatkan akses ke lembaga-lembaga atau instansi-instansi, perusahaan atau pengusaha. Hasil kajian menunjukkan bahwa kinerja penyuluh pertanian dalam mewujudkan akses petani ke lembaga keuangan, informasi sarana produksi pertanian dan pemasaran cukup baik. Hal ini berdasarkan total skor yang diperoleh ialah 37 , dimana pada range nilai 37 berada pada kategori baik. Penyuluh memberikan nilai skor 3 (tiga), karena dalam setiap forum penyuluhan selalu diberikan informasi saprodi pertanian yang baik dan tepat bagi usahatani, terutama dalam upaya mengatasi kelangkaan pupuk/sarana produksi pada saat musim tanam. Penyuluh juga telah memberikan informasi perusahaan-perusahaan atau pengusaha mana yang sekiranya bergerak atau memiliki usaha dibidang agribisnis, serta membuka hubungan kemitraan.Selain itu penyuluh juga telah memberikan informasi bahkan mempertemukan secara langsung dengan pihak lembaga keuangan (bank).

Berbeda halnya dengan pendapat dari petani, sebagian besar petani memberikan nilai skor 2 (dua) karena walaupun telah ada akses ke lembaga keuangan, namun kurangnya petani yang memperoleh pinjaman modal dari bank dan banyaknya persyaratan administrasi ditambah dengan harus adanya jaminan, menyebabkan petani tidak tertarik untuk mencoba mendapatkan pinjaman bank. 
Tabel 6

Hasil Penilaian Responden terhadap Indikator Terwujudnya Kemitraan Usaha Antara Petani dengan Pengusaha

\begin{tabular}{lccc} 
Kategori & Skor & N & Persentase (\%) \\
Memiliki mitra dengan pengusaha & 3 & 0 & 0,00 \\
Belum memiliki mitra dengan pengusaha & 2 & 12 & 30,00 \\
Tidak memiliki mitra dengan pengusaha & 1 & 28 & 70,00 \\
Total & 52 & 40 & 100,00 \\
\hline
\end{tabular}

Sumber : Data Primer Diolah, 2015

Meningkatnya Produktifitas Agribisnis Komoditas Unggulan di Masing-Masing Wilayah Kerja

Pengembangan agribisnis komoditas unggulan merupakan salah satu tujuan utama program pembangunan pertanian. Pengupayaannya dengan memfasilitasi berkembangnya usaha pertanian lebih produktif dan efisien sehingga menghasilkan berbagai produk pertanian yang memiliki nilai tambah dan daya saing tinggi. Berikut hasil penilaian terhadap indikator produktifitas agribisnis komoditas unggulan yang terangkum dalam Tabel 8 . Hasil penilaian pada Tabel 8 menunjukkan bahwa produktifitas agribisnis komoditas unggulan mengalami peningkatan yang tidak signifikan. Program-program penyuluhan yang diberikan telah mampu diterapkan oleh sebagian petani, namun karena keterbatasan pengetahuan dan sikap petani yang merasa puas dengan cara tradisional mengakibatkan peningkatan produktifitas agribisnis komoditas unggulan cukup pelan. Sebagian besar responden yakni sebanyak 19 responden memberi nilai skor 2 (dua) dan hanya 10 (sepuluh) responden memberi nilai skor 3 (tiga), sehingga total skor ialah 37 . Nilai 37 termasuk dalam range kategori yang baik. Kondisi ini menunjukkan bahwa kinerja penyuluh dalam peningkatan produktifitas agribisnis komoditas unggulan sudah baik. Upaya selanjutnya terutama dalam membekali para petani pengetahuan dan kemampuan masih perlu ditingkatkan lagi (kualitas SDM) agar program-program penyuluhan berjalan dengan efektif dan efisien.

Meningkatnya Pendapatan dan Kesejahteraan Petani di Masing-Masing Wilayah Kerja

Segala upaya yang dilakukan oleh penyuluh melalui program-program penyuluhannya bertujuan untuk meningkatkan pendapatan petani yang akan berdampak pula pada kesejahteraan petani. Hasil penilaian terhadap indikator meningkatnya pendapatan dan kesejahteraan petanidapat dilihat pada tabel 9.

$\begin{array}{ccc}\text { Kinerja } & \text { penyuluh dalam } \\ \text { peningkatan } & \text { pendapatan }\end{array}$ kesejahteraan petani sudah baik $\mathrm{Hal}$ ini diperkuat dari hasil penilaian pada Tabel 9 yang memperlihatkan total skor 66 ,

Tabel 7

Hasil Penilaian Responden terhadap Indikator Terwujudnya Akses Petani ke Lembaga Keuangan, Informasi Sarana Produksi Pertanian dan Pemasaran

$\begin{array}{lccc}\text { Kategori } & \text { Skor } & \text { N } & \text { Persentase (\%) } \\ \text { Memiliki akses } & 3 & 12 & 30,00 \\ \text { Kurang memiliki akses } & 2 & 18 & 45,00 \\ \text { Tidak memiliki akses } & 1 & 10 & 25,00 \\ \text { Total } & 82 & 40 & 100,00\end{array}$

Sumber: Data Primer Diolah, 2015 
Tabel 8

Hasil Penilaian Responden terhadap Indikator Meningkatnya Produktifitas Agribisnis

\begin{tabular}{lccc} 
Kategori & Skor & N & Persentase (\%) \\
\hline meningkat pesat & 3 & 10 & 30,00 \\
meningkat perlahan/mulai meningkat & 2 & 19 & 47,50 \\
tidak meningkat / tetap & 1 & 8 & 22,50 \\
Total & 76 & 37 & 100,00 \\
\hline
\end{tabular}

Sumber: Data Primer Diolah, 2015

yang berarti masuk dalam kategori baik. Program -program penyuluh yang telah diberikan dan dijalankan telah memberikan hasil yang cukup memuaskan, hal ini terbukti dari pendapatan petani yang cukup bertambah walaupun tidak terlalu signifikan.

Keseluruhan Hasil Penilaian Terhadap Sembilan Indikator Kinerja Penyuluh Pertanian

Rangkuman hasil penilaian keseluruhan indikator kinerja penyuluh pertanian di Jawa Timur dapat dilihat pada Lampiran 1. Indikator keberhasilan penyuluhan pertanian merupakan kebutuhan dari masyarakat profesional penyuluhan pertanian yang dapat terwujud apabila didukung oleh keberadaan para penyuluh yang kompeten. Pada lampiran 1 memperlihatkan bahwa total skor untuk keseluruhan indikator berjumlah 850 , dimana skor ini berada pada range berkategori sangat baik. Hal ini berarti menunjukkan bahwa kinerja para Penyuluh Pertanian di Jawa Timur sudah sangat baik.

Meskipun demikian masih ada beberapa pekerjaan rumah bagi para penyuluh untuk lebih meningkatkan kinerja mereka terutama dalam hal mengembangkan jalinan kemitraan usaha antara petani dengan pengusaha yang saling menguntungkanagar akses petani ke lembaga keuangan lebih mudah sehingga informasi saprodi pertanian dan pemasaran bisa diimplementasikan oleh seluruh kelompok tani. Dengan demikian petani dapat berdaya dan mandiri dalam mengupayakan agribisnis komoditas unggulan lebih meningkat dengan pesat. Peningkatan signifikan produktifitas agribisnis komoditas unggulan tersebut tentunya akan berimbas pula pada peningkatan pendapatan dan kesejahteraan petani menjadi lebih

\section{Strategi Kebijakan Penyuluhan untuk Meningkatkan Produktivitas Pertanian} Langkah pertama dalam analisis FFA adalah mengidentifikasi faktor pendorong dan faktor penghambat penyuluhan pertanian dalam rangka peningkatan produktivitas pertanian. Berdasarkan hasil identifikasi maka diperoleh faktorfaktor pendorong tersebut sebagai berikut: 1. Kelembagaan penyuluh pertanian baik

2. Kualitas penyuluh pertanian baik

Tabel 9

Hasil Penilaian Responden Terhadap Indikator Meningkatnya Pendapatan dan Kesejahteraan Petani

\begin{tabular}{lccc} 
Kategori & Skor & N & Persentase (\%) \\
\hline meningkat pesat & 3 & 10 & 25,00 \\
meningkat perlahan/mulai meningkat & 2 & 18 & 75,00 \\
tidak meningkat / tetap & 1 & 0 & 0,00 \\
Total & 66 & 38 & 100,00
\end{tabular}

Sumber : Data Primer Diolah, 2015 
Tabel 10

Hasil Perhitungan NU, BF, ND dan NBD Faktor Pendorong

\begin{tabular}{llccccc}
\hline No & \multicolumn{1}{c}{ Fakor Pendorong } & NU & $\begin{array}{c}\text { BF } \\
\text { value }\end{array}$ & $\%$ & ND & NBD \\
\hline D1 & Kelembagaan penyuluh pertanian baik & 4 & 0.20 & 20.00 & 5 & 1.00 \\
D2 & Kualitas penyuluh pertanian baik & 4 & 0.20 & 20.00 & 4 & 0.80 \\
D3 & Kuantitas penyuluh pertanian cukup & 4 & 0.20 & 20.00 & 4 & 0.80 \\
D4 & Kelembagaan kelompok tani yang dinamis & 3 & 0.15 & 15.00 & 4 & 0.60 \\
D5 & Akses informasi yang terbuka dan luas & 2 & 0.10 & 10.00 & 3 & 0.30 \\
D6 & Bantuan pemerintah & 3 & 0.15 & 15.00 & 3 & 0.45 \\
& & 20 & & 100.00 & & \\
\hline
\end{tabular}

Sumber: Data Primer Diolah, 2015

3. Kuantitas penyuluh pertanian cukup

4. Kelembagaan kelompok tani yang dinamis

5. Akses informasi yang terbuka dan luas

6. Bantuan pemerintah

Setelah faktor pendorong diidentifikasi maka langkah selanjutnya adalah diadakan penilaian terhadap faktor-faktor tersebut. Hasil penilaian terhadap faktor-faktor akan menghasilkan Nilai Urgensi Faktor (NU) dan Bobot Faktor (BF). Nilai NU dan BF ditentukan dengan teknik komparasi.

\section{Faktor Pendorong}

Berdasarkan hasil komparasi diperoleh perhitungan seperti pada Tabel 10.

Menentukan Faktor Kunci Keberhasilan: Faktor Kunci Keberhasilan adalah faktor yang memiliki total nilai bobot (TNB) terbesar dari antara faktor-faktor yang berpengaruh terhadap pencapaian misi organisasi. Dari setiap kategori strengths, weaknesses, opportunities dan threats masing-masing dipilih 2 FKK. Cara menentukan FKK adalah sebagai berikut :

- FKK dipilih dari TNB terbesar.

- Kalau TNB sama dipilih BF terbesar.

- Kalau BF sama dipilih NBD terbesar.

- Kalau NBD sama dipilih NBK terbesar.

- Kalau NBK sama, pilih berdasarkan pertimbangan rasionalitas atau pengalaman.

Berdasarkan nilai faktor kunci keberhasilan maka dapat diketahui bahwa nilai FKK Faktor Pendorong yang dipilih adalah : 1. Kelembagaan penyuluh pertanian baik

Tabel 11

Hasil Perhitungan NU, BF, ND dan NBD Faktor Penghambat

\begin{tabular}{llccccc}
\hline No & Faktor Penghambat & NU & $\begin{array}{c}\text { BF } \\
\text { Value }\end{array}$ & $\%$ & ND & NBD \\
\hline H1 & Kurangnya partisipasi petani dalam & 4 & 0.19 & 19.05 & 4 & 0.76 \\
H2 & $\begin{array}{l}\text { Jegiangan penyuluhan } \\
\text { terlalu luan wilayah penyuluhan }\end{array}$ & 3 & 0.14 & 14.29 & 3 & 0.43 \\
H3 & $\begin{array}{l}\text { Dana operasional penyuluhan yang } \\
\text { masih minim }\end{array}$ & 4 & 0.19 & 19.05 & 3 & 0.57 \\
H4 & Pola pikir petani masih tertutup & 3 & 0.14 & 14.29 & 2 & 0.29 \\
H5 & Ketergantungan petani terhadap & 4 & 0.19 & 19.05 & 4 & 0.76 \\
H6 & Pantuan pemerintah & 3 & 0.14 & 14.29 & 2 & 0.29 \\
& 21 & & 100 & & \\
\hline
\end{tabular}

Sumber: Data Primer Diolah, 2015 
Tabel 12

Hasil Perhitungan TNK, NRK, NBK, TNB, FKK Faktor Pendorong

\begin{tabular}{llccccc}
\hline No & Fakor Pendorong & TNK & NRK & NBK & TNB & FKK \\
\hline D1 & Kelembagaan penyuluh pertanian baik & 28 & 2.55 & 0.51 & 1.51 & 1 \\
D2 & Kualitas penyuluh pertanian baik & 32 & 2.91 & 0.58 & 1.38 & 3 \\
D3 & Kuantitas penyuluh pertanian cukup & 34 & 3.09 & 0.62 & 1.42 & 2 \\
D4 & Kelembagaan kelompok tani yang dinamis & 33 & 3.00 & 0.45 & 1.05 & 4 \\
D5 & Akses informasi yang terbuka dan luas & 29 & 2.64 & 0.26 & 0.56 & \\
D6 & Bantuan pemerintah & 42 & 3.82 & 0.57 & 1.02 & \\
& & & & 6.95 & \\
\hline
\end{tabular}

Sumber: Data Primer Diolah, 2015

2. Kuantitas penyuluh pertanian cukup

3. Kualitas penyuluh pertanian baik

4. Kelembagaan kelompok tani yang dinamis

Faktor Penghambat

Seperti halnya perhitungan pada

Faktor pendorong, maka pada faktor penghambat ini mula-mula diidentifikasi faktor-faktor apa saja yang menjadi penghambat pelaksanaan penyuluhan dalam kaitannya dengan peningkatan produktivitas pertanian. Berdasarkan proses identifikasi maka faktor penghambat tersebut adalah sebagai berikut: 1. Kurangnya partisipasi petani dalam kegiatan penyuluhan

2. Jangkauan wilayah penyuluhan terlalu luas

3. Dana operasional penyuluhan yang masih minim

4. Pola pikir petani masih tertutup
5. Ketergantungan petani terhadap bantuan pemerintah

6. Peran penyuluh swasta meningkat Setelah faktor penghambat diidentifikasi maka langkah selanjutnya adalah diadakan penilaian terhadap faktorfaktor tersebut. Penilaian dilakukan dalam rangka mengetahui dan menentukan faktorfaktor mana yang lebih penting, dengan cara membandingkan setiap faktor dengan faktor-faktor yang lain. Hasil penilaian terhadap faktor-faktor akan menghasilkan Nilai Urgensi Faktor (NU) dan Bobot Faktor (BF). Nilai NU dan BF ditentukan dengan teknik komparasi. Berdasarkan hasil komparasi diperoleh perhitungan seperti pada abel 12. Berdasarkan perhitungan FKK baik pada faktor pendorong maupun faktor penghambat maka dapat dilakukan proses penyusunan strategi. Pertama adalah merumuskan tujuan berdasarkan

Tabel 13

Hasil Perhitungan TNK, NRK, NBK, TNB, FKK Faktor Penghambat

\begin{tabular}{|c|c|c|c|c|c|}
\hline Faktor Penghambat & TNK & NRK & NBK & TNB & FKK \\
\hline Kurangnya partisipasi petani dalam & 26 & 2.36 & 0.45 & 1.21 & 1 \\
\hline $\begin{array}{l}\text { kegiatan penyuluhan } \\
\text { Jangkauan wilayah penyuluhan terlalu }\end{array}$ & 44 & 4.00 & 0.57 & 1.00 & 4 \\
\hline $\begin{array}{l}\text { luas } \\
\text { Dana operasional penyuluhan yang }\end{array}$ & 26 & 2.36 & 0.45 & 1.02 & 3 \\
\hline $\begin{array}{l}\text { masih minim } \\
\text { Pola pikir petani masih tertutup }\end{array}$ & 19 & 1.73 & 0.25 & 0.53 & \\
\hline Ketergantungan petani terhadap & 20 & 1.82 & 0.35 & 1.11 & 2 \\
\hline $\begin{array}{l}\text { bantuan pemernintah } \\
\text { Peran penyuluh swasta meningkat }\end{array}$ & 29 & 2.64 & 0.38 & $\begin{array}{l}0.66 \\
5.54\end{array}$ & \\
\hline
\end{tabular}

Sumber : Data Primer Diolah, 2015 
nilai FKK faktor pendorong. Proses perumusan tujuan didasarkan pada pendorong kunci yang dapat diandalkan, guna menghilangkan atau meminimalisasi dampak penghambat kunci; bahwa Kegiatan penyuluhan pertanian harus lebih meningkatkan program-program terkait kelembagaan, kuantitas dan kualitas penyuluh serta perbaikan kelembagaan kelompok tani. Tujuan yang harus dicapai adalah peningkatan mutu penyuluhan pertanian. Sasaran dari tujuan tersebut adalah peningkatan kualitas dan kuantitas penyuluh melalui pendidikan dan pelatihan, serta pemberdayaan kelompok tani.

\section{SIMPULAN}

Dari hasil kajian dapat disimpulkan bahwa kinerja penyuluh pertanian memiliki kategori sangat baik dimana strategi kebijakan penyuluhan yang tepat adalah dengan meningkatkan program-program terkait kelembagaan, kuantitas dan kualitas penyuluh serta perbaikan kelembagaan kelompok tani. Tujuan yang harus dicapai adalah peningkatan mutu penyuluhan pertanian dimana sasaran dari tujuan tersebut adalah peningkatan kualitas dan kuantitas penyuluh melalui pendidikan dan pelatihan, serta pemberdayaan kelompok tani. Oleh karena itu maka rekomendasi yang dapat diajukan sebagai perbaikan kebijakan Pemerintah Provinsi Jawa Timur adalah sebagai berikut: a. meningkatkan kapasitas penyuluh dengan menambah kegiatan TOT atau Bimbingan Teknis terkait teknik komunikasi penyuluhan yang efektif, b. memperbaiki sistem anggaran penyuluhan berbasis aktivitas, c. pelatihan penyuluh untuk membuat laporan kegiatan penyuluhan dan laporan pertanggungjawaban keuangan

\section{DAFTAR PUSTAKA}

Azhar. 2010. Kepuasan Kerja Penyuluh Pertanian di Kabupaten Bogor. Jurnal Penyuluhan Pertanian 5(1): 36-46

Bahua, M.Ikbal. 2010. Faktor-Faktor yang
Mempengaruhi Kinerja Penyuluh Pertanian dan Dampaknya pada Perilaku Petani Jagung Di Provinsi Gorontalo. Jurnal IImiah Agropolitan 3(1): 293-303

Kusmiyati. 2010. Kinerja Penyuluh

Pertanian PNS Dalam

Melaksanakan Tupoksi Di

Kabupaten Bogor (Kasus di BP3K Cibungbulang). Jurnal Penyuluhan Pertanian 5(1): 87-103

Marliati. 2008. Faktor-Faktor Penentu Peningkatan Kinerja Penyuluh Pertanian Dalam Memberdayakan Petani (Kasus di Kabupaten Kampar Provinsi Riau). Jurnal Penyuluhan 4(2): 92-99

Muslihat, E., Azhar., Kusmiyati., \& Indriatmi, W. 2010. Kompetensi Penyuluh Pertanian Dalam Penyususnan Rancangan Usaha Agribisnis Padi Pada BKP5K Kabupaten Bogor Prop Jawa Barat. Agriekonomika 4(2): $132-153$

Mardikanto, Totok. 1993. Penyuluhan Pembangunan Pertanian. Sebelas Maret University Press. Surakarta.

Nazir, Moh. 2005. Metode Penelitian, Ghalia. Jakarta.

Van den Ban, A.W. dan Hawkins, HS. 1999. Penyuluhan Pertanian. Kasinus. Yogyakarta. 
136 | Aryo Fajar Sunartomo, Kapasitas Penyuluh Pertanian

Lampiran 1. Hasil Penilaian Keseluruhan Indikator Kinerja Penyuluh Pertanian di Jawa Timur

\begin{tabular}{|c|c|c|}
\hline Kategori & Skor & Kategori \\
\hline $\begin{array}{l}\text { Tersusunnya program penyuluhan pertanian sesuai } \\
\text { dengan kebutuhan petani (BPP Kabupaten/Kota). }\end{array}$ & 120 & Sangat baik \\
\hline $\begin{array}{l}\text { Tersusunnya kerja penyuluhan pertanian di wilayah } \\
\text { kerja masing-masing. }\end{array}$ & 117 & Sangat baik \\
\hline $\begin{array}{l}\text { Tersedianya data peta wilayah untuk pengembangan } \\
\text { teknologi spesifik lokasi sesuai dengan perwilayahan } \\
\text { komoditas unggulan. }\end{array}$ & 115 & Sangat baik \\
\hline $\begin{array}{l}\text { Terdiseminasinya informasi teknologi pertanian } \\
\text { secara merata dan sesuai dengan kebutuhan petani }\end{array}$ & 114 & Sangat baik \\
\hline $\begin{array}{l}\text { Tumbuh kembangnya keberdayaan dan kemandirian } \\
\text { petani, kelompok tani, kelompok usaha/asosiasi dan }\end{array}$ & 108 & Sangat baik \\
\hline $\begin{array}{l}\text { Terwujudnya kemitraan usaha antara petani dengan } \\
\text { pengusaha yang saling menguntungkan }\end{array}$ & 52 & Kurang Baik \\
\hline $\begin{array}{l}\text { Terwujudnya akses petani ke lembaga keuangan, } \\
\text { informasi sarana produksi pertanian dan pemasaran }\end{array}$ & 82 & Baik \\
\hline $\begin{array}{l}\text { Meningkatnya produktifitas agribisnis komoditas } \\
\text { unggulan di masing-masing wilayah kerja unggulan } \\
\text { di masing-masing wilayah kerja }\end{array}$ & 76 & Baik \\
\hline $\begin{array}{l}\text { Meningkatnya pendapatan dan kesejahteraan petani } \\
\text { di masing-masing wilayah kerja }\end{array}$ & 66 & Kurang Baik \\
\hline Total & 850 & Sangat Baik \\
\hline
\end{tabular}

Sumber : Data Primer diolah, 2015 